\author{
Дејан Мандарић ${ }^{1}$, Сања Мандарић ${ }^{2}$ \\ ${ }^{1}$ Основна школа „Јован Јовановић Змај“, Кањижа \\ ${ }^{2}$ Факултет спорта и физичког васпитања, Универзитет у Београду
}

УДК 796.093.6:796.092.2“1984/2015“

АНАЛИЗА СВЕТСКИХ РЕКОРДА У ДЕСЕТОБОЈУ ОД 1984. ДО 2015. ГОДИНЕ

\title{
Сажетак
}

Десетобој је атлетска дисциплина, која представља такмичење у десет атлетских дисциплина, у којој се такмиче најсвестранији атлетичари. Такмичење у десетобоју одвија се током два дана, а дисциплине су: првог дана - 100 m, скок удаљ, бацање кугле, скок увис, 400 m, а другог дана - 110 m препоне, бацање диска, скок мотком, бацање копља, $1500 \mathrm{~m}$. Сваки остварен резултат у десетобоју се процењује бодовним таблицама, које су 1984. усвојене од стране Међународне атлетске федерације. С обзиром на тркачке, скакачке и бацачке дисциплине десетобоја, циљ рада је да се утврди структура, односно доминантност одређених појединачних дисциплина или група дисциплина, приликом постизања светског рекорда. Сходно томе, у раду је извршена анализа светских рекорда пет најбољих десетобојаца свих времена, Ештона Итона, Романа Шебрлеа, Томаша Дворжака, Ден О'Брајана и Дејли Томпсона. Резултати истраживања указују, да је за постизање врхунског спортског резултата у десетобоју потребан спој како просечних резултата у дисциплинама у којима је десетобојац слабији, тако и постизање натпросечних резултата у дисциплинама које су му јача страна.Уједно, анализа светских рекорда од 1984. до 2015. указује, да су светски рекордери постизали врхунски резултат на себи својствен начин, али и да за многе то није био максимум. Сходно анализи постигнутих резултата, очекује се да ће на Олимпијским играма 2016. у Рио де Жанеиру, Ештон Итон остварити нови светски рекорд.

КљУчне речи: ДЕСЕТОБОЈЦИ / БОДОВНЕ ТАБЛИЦЕ / ЛИЧНИ РЕКОРД / ВРХУНСКИ РЕЗУЛТАТ 


\section{ANALYSIS OF WORLD RECORDS IN THE DECATHLON FROM 1984 TO 2015}

\section{Summary}

The decathlon is a combined event in athletics consisting of ten track and field events, where the most versatile athletes compete. The decathlon competition is held over two days, and the winners are determined by the combined performance in all. On the first day the competitors do $100 \mathrm{~m}$, long jump, shot put, high jump and 400 $\mathrm{m}$. On the second day they do $110 \mathrm{~m}$ hurdles, discus throw, pole vault, javelin throw and $1500 \mathrm{~m}$. Performance is judged on a points system in each discipline using scoring tables, which were accepted in 1984 by the International Association of Athletics Federation. Considering that the decathlon stands for running, jumping, and throwing disciplines, the goal of the project is to determine the structure, or domination of definite single disciplines or the group of disciplines, during achieving the world record. According to this, the analysis of world records of five best decathletes Ashton Eaton, Roman Šeble, Tomáš Dvořák, Dan O’Brien and Daley Thompson was done in this project. The research results show that the combination of both achieving average results in disciplines where the decathlete is weaker, and achieving above average results in disciplines which are his strengths is required to achieve top sports results in the decathlon. At the same time, the analysis of world records from 1984 to 2015 show that the world recorders achieved the top results in their own way, but they also show that was not their maximum. According to the analysis of the achieved results, it is expected for Ashton Eaton to achieve the new world record at the Rio 2016 Olympic Games.

Key words: DECATHLETES / SCORING TABLES / PERSONALE BEST / HIGH PERFORMANCE 


\section{1. Увод}

Како подвући црту испод античког вишебојца Ламписа, легенде Џима Торпа, „велике резерве“ Ден О'Брајана, „цара“ Романа Шебрлеа или „ванземаљца“ Ештона Итона, који су кроз историју „краљевске дисциплине“ атлетици дали неизбрисиви печат и поставили десетобој на пиједестал спортских достигнућа, не само као атлетску дисциплину, већ скоро као начин живота.

Десетобој је атлетско такмичење које се састоји из десет различитих атлетских дисциплина, које се одвијају у два узастопна дана, а победник је онај такмичар који постигне највећи број бодова. Реч десетобој потиче од грчке речи $\delta \dot{\varepsilon} к \alpha$ (дека) - десет и $\theta \lambda о \varsigma$ (атлос) - подвиг, изазов (Longman Dictionary, 2003, стр. 405) и први пут је коришћена у Скандинавији, тачније у Данској и Шведској. Наиме, на Олимпијским играма у Стокхолму 1912. године организовано је прво такмичење у десетобоју (Bergvall, 1913).

Према правилима Међународне атлетске федерације (International Association of Athletics Federation) дисциплине десетобоја одвијају се по следећем распореду: први дан - $100 \mathrm{~m}$, скок удаљ, бацање кугле, скок увис, 400 m; други дан - 110 m препоне, бацање диска, скок мотком, бацање копља, 1500 m.

Сваки остварени резултат у појединачним дисциплинама десетобоја се процењује на основу бодовних таблица усвојених 1984.од стране Међународне атлетске федерације (Trkal, 2004).Победник је онај десетобојац који има највише бодова после свих десет дисциплина.У складу са наведеним, десетобој је једино такмичење у коме није битно да ли је спортиста први, трећи или последњи у одређеној дисциплини. Битан је укупан број освојених бодова, а десетобојац се заправо такмичи против својих сопствених могућности и стандарда. ${ }^{36,37}$ Резултат од 8000 бодова (просечно 800 бодова по дисциплини) спада у ред високог спортског достигнућа, иако чешки тренери указују на „Модел 8200 “ (Wang \& $L u$, 2007).

Десетобојац не мора да буде изузетан ни у једном делу такмичења, да би био шампион у свих десет. Мора да буде добар у дисциплинама у којима је слабији и да се истиче у дисциплинама које су му јача страна. С обзиром да, мора да буде добар у три спринтерске, три скакачке и три бацачке дисциплине и

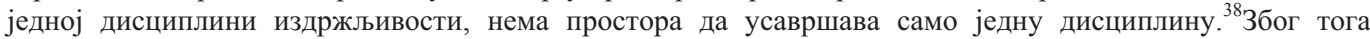
десетобојац мора правити компромис, и у томе лежи сама природа десетобоја.То је компромис у коме се морају правити уступци у припремама са циљем постизања максималног резултата (Tidow, 2000).

Током тренинга се тежи ка усавршавању технике, стицању снаге, а да то не утиче на брзину или скочност и обратно, као и да се стекне издржљивост, која ће десетобојца пратити кроз такмичење које

\footnotetext{
${ }^{36}$ Ретко је у десетобоју противник други спортиста. Води се битка против времена, даљине, замора и унутрашњих страхова од слабости, неуспеха, али и против бодова. Десетобојац је сам свој противник. Сваки десетобојац се труди да постигне најбољи резултат, без жеље да умањи туђе напоре.

${ }^{37}$ Психички фактори играју велику улогу у десетобоју. Многи тренери причају о „десетобојском менталитету“ што би значило способност спортисте да остане сконцентрисан током десет дисциплина, да се психички спреми за сваки покушај или трку, преболи разочарање и да настави са следећим изазовом. У десетобоју постоје шансе да се надокнади изгубљено тј. пропуштено.

${ }^{38}$ Главни тренер вашингтонског атлетског тима, Рик Слоун (Rick Soan), каже да се десетобој може упоредити са обртањем десет керамичких тањира на штаповима. Потребно их је што дуже и што брже окретати, а при томе и пазити, да неки од њих не падну. Неке од „тањира“ треба окретати снажније, неки од „тањира“ брзо почињу „падати“, те их је поново потребно вратити и „окретати слабије“', не заборављајући и „снажније“'.То би, по његовом, била најједноставнија „филозофија“" десетобоја. (http://www.decathlon2000.com/)
} 
врло често траје од осам до десет сати дневно (Bilić, Balić, 2015; Ryba, 2002; Tidow, 2000; Ván̆a, 2002; Wolf et all, 2007; Wang \& Lu, 2007).

Структуру десетобоја као атлетске дисциплине чине три велике групе атлетских дисциплина и то: тркачке, скакачке и бацачке дисциплине. Анализом резултата преко 8000 бодова од 1966. до 2002. године које су десетобојци остваривали, диференцирало се неколико модела десетобојаца. Тако су модели десетобојца до 1980. били модел бацача, скакача и тркача, а након тога тркач-скакач, скакач-бацач и тркач-бацач (Cox \& Dunn,2002; Kenny et al., 2005), док данас савремени модел десетобојца захтева равномерност у свим дисциплинама.

Вулф и сарадници (2007) на основу резултата од 1986. до 2005. дефинишу кластере у дисциплинама вишебоја, те тако први кластер представљају спринтерска трчања и скок удаљ, други кластер преостале скакачке дисциплине, трећи кластер бацачке дисциплине, док је трка на $1500 \mathrm{~m}$ самостални кластер. У свом истраживању Билићева (2015) наводи да, кључне одреднице успешности у десетобоју чине техничка ефикасност (скок мотком) и ефикасност испољавања енергетских капацитета, односно аеробноанаеробне компоненте (трчање $1500 \mathrm{~m}$ ). Међутим, без изразите доминације спринтерских квалитета није могуће остварити резултат на нивоу десетобојских рекордера.

У данашње време уочавају се све бољи резултати у спринтерским дисциплинама, скоку удаљ и скоку мотком, тако да се у скорије време може очекивати видан напредак у десетобоју, али и могућност диференцирања нових модела десетобојаца.

На основу свега наведеног, предмет рада су светски рекорди у десетобоју од 1984. до 2015. године. Према званичним подацима Међународне асоцијације атлетских федарација, пет најбољих десетобојаца свих времена су Ештон Итон (Ashton Eaton), Роман Шебрле (Roman Šebrle), Томаш Дворжак (Tomáš Dvořák), Ден О'Брајан (Dan O'Brien) и Дејли Томпсон (Daley Thompson). С обзиром да су, пет најбољих десетобојаца свих времена светске рекорде постизали у периоду од 1984. до 2015, циљ рада је да се утврди структура светских рекорда Дејли Томпсона, Ден О'Брајана, Томаша Дворжака, Романа Шебрлеа и Ештона Итона.

\section{2. Метод}

У раду је примењен метод анализе светских рекорда најбољих десетобојаца у периоду од 1984. до 2015. године, Дејли Томпсона, Ден О'Брајана, Томаша Дворжака, Романа Шебрлеа и Ештона Итона. Поред тога, анализирани су њихови најбољи резултати у периоду од седам година, а упоредном анализом пет светских рекорда, дефинисана је њихова структура, као и доминантне групе дисциплина. Израчунавањем индекса успешности, одређен је ниво могућности који је сваки светски рекордер испољио током постизања светског рекорда.

\section{3. Резултати истраживања са дискусијом}

\section{1. Анализа постигнутих светских рекорда од 1984. до 2015. године}

\subsection{1. Анализа најбољих резултата светског рекордера Дејли Томпсона}

Дејли Томпсон био је неприкосновени владар десетобоја 80-их година прошлог века, а уједно се сврстава у ред најбољих атлетичара свих времена. Он је једини десетобојац који је освојио две златне олимпијске медаље и титулу првака света. У његовој богатој каријери се налази и златна европска медаља, а и четири пута је обарао светски рекорд. 
Табела1 Резултати најбољих десетобоја Дејли Томпсона у периоду од 1978. до1984. године

\begin{tabular}{|l|c|c|c|c|c|c|c|}
\hline Година наступа & 1978 & 1979 & 1980 & 1981 & 1982 & 1983 & 1984 \\
\hline Година старости & 20 & 21 & 22 & 23 & 24 & 25 & 26 \\
\hline \hline Десетобој & 8470 & - & 8648 & 7797 & 8774 & 8714 & 8847 СР \\
\hline \hline 100 m & 10,50 & 10,45 & 10,55 & 10,47 & 10,51 & 10,60 & 10,44 \\
\hline Скок удаљ & 8,11 & 7,60 & 7,72 & 7,84 & 7,80 & 7,88 & 8,01 \\
\hline Бацање кугле & 14,43 & 14,82 & 14,46 & 14,54 & 15,44 & 15,35 & 15,72 \\
\hline Скок увис & 2,07 & 2,06 & 2,11 & 2,05 & 2,03 & 2,03 & 2,03 \\
\hline 400 т & 47,85 & 47,30 & 48,04 & 47,64 & 47,11 & 48,12 & 46,97 \\
\hline 110 т препоне & 14,92 & 14,39 & 14,37 & 14,81 & 14,39 & 14,37 & 14,33 \\
\hline Бацање диска & 41,68 & 43,14 & 42,98 & 41,66 & 45,48 & 44,46 & 46,56 \\
\hline Скок мотком & 4,80 & без. рез. & 4,90 & 5,00 & 5,00 & 5,10 & 5,00 \\
\hline Бацање копља & 56,60 & 61,92 & 65,38 & 62,54 & 63,56 & 65,24 & 65,24 \\
\hline 1500 т & $4: 25,78$ & није старт. & $4: 25,49$ & није старт. & $4: 23,72$ & $4: 29,72$ & $4: 35,00$ \\
\hline
\end{tabular}

Анализирајући резултате из 1984. године у којој је овај врсни десетобојац оборио светски рекорд, може се констатовати, да се Томпсон шест година развијао у светског рекордера, јер је са 20 година остварио већ резултат од 8470 бодова. Сви резултати у појединачним дисциплинама су показивали да је Томпсон одличан тркач и скакач.Требало је пуних шест година, да овај врсни десетобојац задржи висок ниво спортских резултата у овим дисциплинама, а да поправи резултате у бацачким дисциплинама. На основу резултата у табели 1, уочава се да је Томпсон, у свом рекордном десетобоју подбацио у овим дисциплинама. Лични рекорд на $100 \mathrm{~m}$ му је био $10.26 \mathrm{~s}$, а он је истрчао $10.44 \mathrm{~s}$, у скоку удаљ најбољи резултат му је био $8.11 \mathrm{~m}$, а он је скочио $8.01 \mathrm{~m}$, док је у скоку у вис подбацио за 8 ст и скочио за њега скромних $2.03 \mathrm{~m}$. Међутим, Томпсон је остварио одличне резултате у бацачким дисциплинама и то: бацању кугле $(15.72 \mathrm{~m})$ и бацању копља $(65.24 \mathrm{~m})$. Поставља се питање, да ли би његов резултат био бољи да је у скакачким и тркачким дисциплинама био на свом највишем нивоу. Претпоставка је да би био, јер је и у трци на $1500 \mathrm{~m}$ био далеко од свог најбољег резултата. Његов постигнути резултат је за скоро 100 бодова слабији од његовог најбољег остварења, тако да би и укупан резултат био знатно бољи.

\subsection{2. Анализа најбољих резултата светског рекордера Ден О'Брајана}

Када се говори о Денијелу Диону О'Брајану (Daniel Dion O'Brien), или познатије атлетској и светској јавности Ден О'Брајану, може се одмах на почетку рећи, да је био атлетичар са можда највећим потенцијалом за постизање врхунског остварења у десетобоју. Многи атлетски стручњаци и такмичари сматрају да је он био десетобојац за много боље резултате него оне које је постизао. Анализирајући његов светски рекорд, као и појединачне резултате, може се уочити невероватна брзина за једног 
десетобојца, затим одлични резултати у скакачким дисциплинама, али и висок ниво резултата у бацачким дисциплинама. Иако је био врхунски десетобојац, у свом рекордном десетобоју је подбацио баш у оним дисциплинама које су биле његова јача страна. ${ }^{39}$ Интересантно је напоменути, да је свој рекордни десетобој остварио у 26. години, као и његов претходник Томпсон.

Освојио је светско првенство 1991, 1993. и 1995, а 1992. године, оборио је светски рекорд, док је круна његове каријере освојена златна медаља на Олимпијским играма 1996. године у Атланти.

Табела 2 Резултати најбољих десетобоја Ден О'Брајана у периоду од 1990. до1996. године.

\begin{tabular}{|l|c|c|c|c|c|c|c|}
\hline Година наступа & 1990 & 1991 & 1992 & 1993 & 1994 & 1995 & 1996 \\
\hline Година старости & 24 & 25 & 26 & 27 & 28 & 29 & 30 \\
\hline \hline Десетобој & 8483 & 8844 & $8891 \mathrm{CP}$ & 8817 & 8715 & 8695 & 8824 \\
\hline \hline $100 \mathrm{~m}$ & 10,40 & 10,23 & 10,43 & 10,57 & 10,49 & 10,57 & 10,50 \\
\hline Скок удаљ & 8,04 & 7,96 & 8,08 & 7,99 & 7,81 & 7,55 & 7,57 \\
\hline Бацање кугле & 15,36 & 16,06 & 16,69 & 15,41 & 15,70 & 14,82 & 15,66 \\
\hline Скок увис & 2,13 & 2,08 & 2,07 & 2,03 & 2,20 & 2,13 & 2,07 \\
\hline 400 m & 49,25 & 47,70 & 48,51 & 47,46 & 47,74 & 47,81 & 46,82 \\
\hline 110 т препоне & 14,03 & 13,95 & 13,98 & 14,08 & 13,81 & 13,78 & 13,87 \\
\hline Бацање диска & 46,04 & 48,08 & 48,56 & 47,92 & 48,10 & 46,92 & 48,78 \\
\hline Скок мотком & 4,30 & 5,10 & 5,00 & 5,20 & 4,90 & 5,20 & 5,00 \\
\hline Бацање копља & 58,16 & 57,40 & 62,58 & 62,56 & 62,20 & 62,90 & 66,90 \\
\hline 1500 m & $4: 43,90$ & $4: 45,54$ & $4: 42,10$ & $4: 40,08$ & $5: 10,94$ & $4: 52,52$ & $4: 45,89$ \\
\hline
\end{tabular}

Анализом резултата О'Брајана може се закључити да су сви његови резултати у појединачним дисциплинама били врхунска достигнућа. Скакачке дисциплине су му биле најјаче и у њима је освајао највише бодова. Када се погледају његови резултати скока у даљ од $8.11 \mathrm{~m}$, скока увис од $2.20 \mathrm{~m}$ и скока мотком од $5.25 \mathrm{~m}$ закључује се, да се могао равноправно такмичити и са најбољим атлетичарима у овим дисциплинама. Тркачке дисциплине су му такође биле одличне, а најбољи резултати су му на $100 \mathrm{~m}$ $10.23 \mathrm{~s}$ и на $110 \mathrm{~m}$ препоне $13.47 \mathrm{s.}{ }^{40}$ Што се тиче бацачких дисциплина, његови резултати у овим дисциплинама су били у групи најбољих резултата које су постизали десетобојци. Резултат у диску од $55.07 \mathrm{~m}$ је и најбољи резултат у историји десетобоја. Даљом анализом његових резултата уочава се изузетно просечан резултат у бацању копља. Најбоље остварење у овој дисциплини му је био резултат од $66.90 \mathrm{~m}$, а у просеку је остваривао даљине од 61 до 64 метра. Ови резултати нису у корелацији са резултатима у бацању диска, бацању кугле и са резултатом на 100 m, јер се на основу ових параметара

\footnotetext{
${ }^{39}$ Ден Обрајан је често говорио „Знате, десетобој не бирате ви, него десетобој бира вас.”.И баш тако је Ден постао један од највећих, ако не и највећи десетобојац свих времена.

${ }^{40}$ Једном је и сам О'Брајан изјавио да би по завршетку каријере у десетобоју могао трчати баш дисциплину са препонама.
} 
може извести закључак да је требао бацати много више. Његова још једна лошија дисциплина била је трка на 1500 метара.

Када неко обори светски рекорд он обично премаши границе својих могућности и каже се да је био одличан, феноменалан. Анализирајући О'Брајанов светски рекорд може се закључити да је његов светски рекорд био добар. Једноставно О'Брајан приликом обарања светског рекорда није био близу својих најбољих остварења. Наиме, он је био добар, а у односу на остале такмичаре супериоран да је, и са лошијим резултатима од својих најбољих достигнућа победио, па чак и оборио светски рекорд. Ова чињеница наводи на један закључак, који указује да је О'Брајан могао много више. Његов светски рекорд од 8891 бодова би био много бољи да није „подбацио“ у неким дисциплинама.

\subsection{3. Анализа најбољих резултата светског рекордера Томаша Дворжака}

Томаш Дворжак је одувек био екстравагантна појава на такмичењима. За време такмичења носио је тамне наочаре, а често је и мењао боју косе. Иако су га многи сматрали за кловном на стази, његови резултати су били фантастични. Убрзо га је атлетски свет прихватио и сврстао у ред најбољих такмичара на планети.

Велике промене у његовој каријери су донеле Олимпијски игре 1996. у Атланти. Освојио је бронзану медаљу са 8664 бодова, а тај резултат је био и државни рекорд Чешке. Убрзо после тога Дворжак постаје десетобојац кога се сви прибојавају, а на Светском првенству у Атини 1997. осваја златну медаљу. Тада је уједно поставио и нови државни рекорд Чешке који је износио 8837 бодова. На Европском Купу 1999. у Прагу, гледаоци су имали прилике да присуствују стварању историје. Наиме, Дворжак не само да је оборио светски рекорд са постигнутих 8994 бода, него се и приближио магичној граници од 9000 бодова. 
Табела 3 Резултати најбољих десетобоја Томама Дворжака у периоду од 1994. до 2000. године.

\begin{tabular}{|l|c|c|c|c|c|c|c|}
\hline Година наступа & 1994 & 1995 & 1996 & 1997 & 1998 & 1999 & 2000 \\
\hline Година старости & 22 & 23 & 24 & 25 & 26 & 27 & 28 \\
\hline \hline Десетобој & 8313 & 8347 & 8664 & 8837 & 8592 & $8994 \mathrm{CP}$ & 8900 \\
\hline $100 \mathrm{~m}$ & 10,83 & 10,74 & 10,64 & 10,60 & 10,67 & 10,54 & 10,54 \\
\hline Скок удаљ & 7,75 & 7,73 & 7,60 & 7,64 & 7,58 & 7,90 & 8,03 \\
\hline Бацање кугле & 15,52 & 15,40 & 15,82 & 16,32 & 15,50 & 16,78 & 16,68 \\
\hline Скок увис & 2,04 & 2,01 & 1,98 & 2,00 & 2,00 & 2,04 & 2,09 \\
\hline 400 m & 48,36 & 48,34 & 48,29 & 47,56 & 48,04 & 48,08 & 48,36 \\
\hline 110 т препоне & 14,20 & 14,39 & 13,79 & 13,61 & 13,84 & 13,73 & 13,89 \\
\hline Бацање диска & 41,04 & 42,26 & 46,28 & 45,16 & 45,95 & 48,33 & 47,89 \\
\hline Скок мотком & 4,40 & 4,60 & 4,70 & 5,00 & 4,70 & 4,90 & 4,85 \\
\hline Бацање копља & 62,16 & 61,32 & 70,16 & 70,34 & 70,64 & 72,32 & 67,21 \\
\hline 1500 m & $4: 32,67$ & $4: 31,96$ & $4: 31,25$ & $4: 35,40$ & $4: 41,19$ & $4: 37,20$ & $4: 42,33$ \\
\hline
\end{tabular}

Дворжак је прототип чешке школе десетобоја. Одликовале су га одлична техника, што му је омогућило да буде приближно добар у свим дисциплинама. Није имао велике разлике између скакачких, тркачких и бацачких дисциплина. Психолошки је био веома стабилан, тако да није имао превеликих осцилација у резултату.

Иако се међу стручњацима у атлетском спорту сматрало да би О’Брајан требао бити вишебојац који ће остварењем премашити 9000 бодова, ипак му то није успело. Његов светски рекорд је срушио прототип чешке школе десетобоја,Томаш Дворжак. Анализирајући његове резултате, може се закључити да је овај десетобојац поред брзине и добре скочности, направио више него добре резултате у бацачким дисциплинама. Резултат у бацању кугле од $16.78 \mathrm{~m}$ је одличан резултат за десетобојце. Ако се направи поређење са О'Брајановим резултатом, може се закључити да је он за нијансу био бољи. Међутим, Дворжак је отишао корак даље, не само да је постигао одличан резултат у бацању диска од $48.08 \mathrm{~m}$, већ је и свој лични рекорд у бацању копља померио за 2 метра. На тај начин, резултат од $72.32 \mathrm{~m}$ не само да му је омогућио постизање светског рекорда, него и приближавање магичној граници од 9000 бодова. Интересантно је, да је Дворжак и поред резултата од 48.08 s на $400 \mathrm{~m}$, што је добар резултат, имао проблема са брзинском издржљивошћу. Да је у трци на 1500 m истрчао за 4:36.20 минута, Дворжак би тада био први атлетичар, који је у десетобоју освојио преко 9000 бодова. 


\subsection{4. Анализа најбољих резултата светског рекордера Романа Шебрлеа}

Роман Шебрле је један од најбољих пријатеља, а и колега из групе Томаша Дворжака, који је дуго година био у сенци свог најбољег пријатеља, а у исто време свог највећег противника.41Међутим то му није сметало, чак је и говорио да је свака Дворжакова победа његова. Многи су сматрали да ће Шебрле остати заувек у сенци свога пријатеља. Као што је сам говорио, многе Дворжакове медаље, па и светски рекорд су га мотивисали да још квалитетније и напорније тренира (Váňa, 2002).Тако је 2001. Шебрле прешао магичну границу од 9000 бодова, поставивши нови светски рекорд који је тада износио 9026 бодова. После овог такмичења просто је било немогуће победити Шебрлеа. Ређали су се бројни успеси, а као круна његове каријере је освојена златна медаља на Олимпијским играма 2004. у Атини.

Табела 4 Резултати најбољих десетобоја Романа Шебрлеа у периоду од 1995. до 2001. године.

\begin{tabular}{|l|c|c|c|c|c|c|c|}
\hline Година наступа & 1995 & 1996 & 1997 & 1998 & 1999 & 2000 & 2001 \\
\hline Година старости & 21 & 22 & 23 & 24 & 25 & 26 & 27 \\
\hline \hline Десетобој & 7642 & 8210 & 8380 & 8589 & 8527 & 8757 & 9026 СР \\
\hline \hline $100 \mathrm{~m}$ & 11.29 & 10.85 & 10.70 & 10.73 & 10.74 & 10.64 & 10.64 \\
\hline Скок удаљ & 7.29 & 7.65 & 7.72 & 8.03 & 7.73 & 7.88 & 8.11 \\
\hline Бацање кугле & 13.11 & 14.24 & 15.09 & 15.43 & 14.77 & 15.19 & 15.33 \\
\hline Скок увис & 2.02 & 2.10 & 2.07 & 2.07 & 2.13 & 2.15 & 2.12 \\
\hline $400 \mathrm{~m}$ & 50,22 & 49,94 & 48,75 & 49,56 & 48,02 & 49,05 & 47,79 \\
\hline $110 \mathrm{~m}$ препоне & 15,34 & 14,49 & 14,48 & 14,12 & 13,93 & 13,99 & 13,92 \\
\hline Бацање диска & 40,80 & 41,86 & 42,34 & 45,80 & 45,12 & 47,21 & 47,92 \\
\hline Скок мотком & 4,60 & 4,60 & 4,80 & 4,80 & 4,60 & 4,75 & 4,80 \\
\hline Бацање копља & 60,04 & 64,28 & 65,60 & 65,08 & 64,06 & 67,23 & 70,16 \\
\hline $1500 \mathrm{~m}$ & $4: 45,85$ & $4: 39,80$ & $4: 48,31$ & $4: 49,94$ & $4: 42,48$ & $4: 35,06$ & $4: 21,98$ \\
\hline
\end{tabular}

Када се анализира светски рекорд Шебрлеа, може се уочити да је поред брзине, код њега била изражена и експлозивна снага. Одлични резултати у скоку удаљ $8.11 \mathrm{~m}$ и у скоку увис $2.12 \mathrm{~m}$ показују да је своје физичке способности (брзину и скочност) могао да искористи у овим дисциплинама. Поред, до тада најбоље постигнутих резултата на $400 \mathrm{~m}$ (47.79 s), $110 \mathrm{~m}$ препоне (13.92 s), у бацању диска, кугле и копља, постигао је одличне резултате и у осталим дисциплинама. По мишљењу многих стручњака и

\footnotetext{
${ }^{41}$ Роман је често говорио да му је Дворжак највећа инспирација у десетобоју. Људи су га често називали сребрним краљем, а многи су говорили да је било боље да је рођен у некој другој држави, јер би на тај начин био прослављени атлетичар.
} 
поред ових одличних резултата, светски рекорд му је донела трка на 1500 метара. Иако је по правилу ово једна од најслабијих дисциплина десетобојаца, Шебрле је постигао одличан резултат 4:21.08 и на тај начин оборио светски рекорд. Његов најбољи резултат у десетобоју до тада је износио 8757 бодова, са резултатом 4:35.06 на 1500 метара. Својим остварењем у трци на $1500 \mathrm{~m}$, не само да је поправио свој најбољи резултат, него је и оборио светски рекорд.

3.1.5.Анализа најбољих резултата светског рекордера Аштона Итона

Ештон Итон је тренутно важећи светски рекордер (9045) и најбољи десетобојац свих времена. Итон не само што је 2015. на Светском првенству у Пекингу постигао резултат преко „магичних“ 9000 бодова, већ је то учинио и 2012. (9039) и тако себе сврстао у десетобојца који је, за сада, два пута у својој спортској каријери остварио резултат преко 9000 бодова. Златну олимпијску медаљу освојио је на Олимпијским играма 2012. у Лондону, а титулу светског првака, поред овогодишње титуле, и 2013. на Светском првенству у Москви. 
Табела 5 Резултати најбољих десетобоја Ештона Итона у периоду од 2009. до 2015. године

\begin{tabular}{|l|c|c|c|c|c|c|c|}
\hline Година наступа & 2009 & 2010 & 2011 & 2012 & 2013 & 2014 & 2015 \\
\hline Година старости & 21 & 22 & 23 & 24 & 25 & 26 & 27 \\
\hline Десетобој & 8091 & 8457 & 8729 & 9039 & 8809 & није такм. & 9045 СР \\
\hline $100 \mathrm{~m}$ & 10,49 & 10,37 & 10,33 & 10,21 & 10,35 & - & 10,23 \\
\hline Скок удаљ & 7,45 & 7,90 & 7,80 & 8,23 & 7,73 & - & 7,88 \\
\hline Бацање кугле & 12,63 & 12,60 & 14,14 & 14,20 & 14,39 & - & 14,52 \\
\hline Скок увис & 2,00 & 2,02 & 2,05 & 2,05 & 1,93 & - & 2,01 \\
\hline 400 т & 47,12 & 46,28 & 46,35 & 46,70 & 46,02 & - & 45,00 \\
\hline 110 т препоне & 14,01 & 13,68 & 13,52 & 13,70 & 13,72 & - & 13,69 \\
\hline Бацање диска & 39,80 & 41,71 & 41,58 & 42,81 & 45,00 & - & 43,34 \\
\hline Скок мотком & 4,85 & 5,10 & 5,05 & 5,30 & 5,20 & - & 5,20 \\
\hline Бацање копља & 49,68 & 52,41 & 56,19 & 58,87 & 64,83 & - & 63,63 \\
\hline 1500 m & $4: 35,56$ & $4: 21,85$ & $4 ; 24,10$ & $4: 14,48$ & $4: 29,80$ & - & $4: 17,52$ \\
\hline
\end{tabular}

Већ у свом првом десетобоју преко 8000 бодова, Итон је показао да ће бити један од најбољих вишебојаца свих времена. У том десетобоју и поред јако лоших реултата у бацачким дисциплинама (бацање кугле - $12.63 \mathrm{~m}$; бацање диска $39.80 \mathrm{~m}$ ), успео је остварити резултат од 8091 бодова. На основу анализе резултата приказаних у табели 5 , може се заузети став, да за Итона не постоје границе у десетобоју. Резултати указују да Итон поседује природан таленат са израженим спринтерско-скакачким особинама (100 m - 10.21; $400 \mathrm{~m}-45.00 ; 110 \mathrm{~m}$ препоне - 13.69; скок удаљ - 8.23 m и скок мотком $5.30 \mathrm{~m})$. Уједно, поред овако сјајних резултата у спринтерско-скакачким дисциплинама, невероватна је његова способност да у последњој дисциплини десетобоја, трци на $1500 \mathrm{~m}$ трчи за 4:14.48 или 4:17.52 s. Оба ова резултата Итон је постигао приликом остварења резултата преко 9000 бодова (9039; 9045). Са развојем бацачких дисциплина, које су сразмерно пратиле и напредак у осталим дисциплинама Итон је постао најбољи десетобојац свих времена, „краљ, краљице спортова“. На овај начин, Итон „ствара“ један нови поглед и нову димензију десетобоја као најсвестраније атлетске дисциплине. Увидом у Итонове резултате, долази се до закључка, да су његови резултати у појединим дисциплина толико добри, да многи од њих могу бити национални рекорди појединих земаља, а за очекивати је да ће он границе у десетобоју још померати. 


\section{2. Упоредна анализа светских рекорда у десетобоју од 1984. до 2015. године}

Анализа постигнутих светских рекорда у десетобоју у периоду од 1984. до 2015. године, приказаних графиконом 1, указује на њихову прогресију. Највећи напредак уочава се постизањем Дворжаковог светског рекорда (8994), који је за 103 бода био бољи од О'Брајановог (8891). Најмања разлика у постигнутим светским рекордима (19 бодова) уочава се између Шебрлеовог (9026) и Итоновог (9045) резултата. Најдуже је трајао светски рекорд Шебрлеа (14 година), а најмање рекорд Дворжака (2 године).

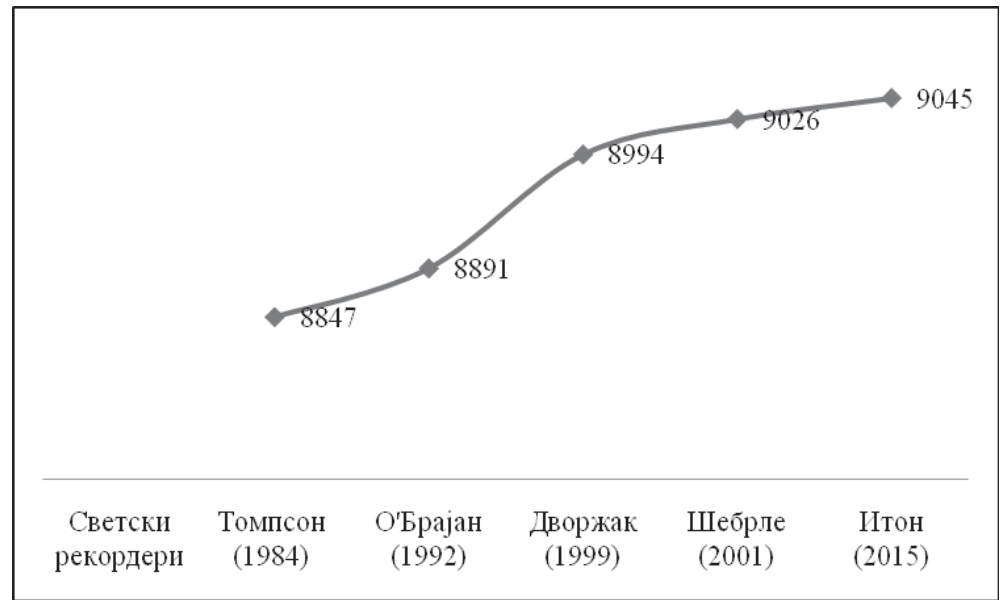

Графикон 1 Развој светских рекорда од 1984. до 2015. године.

У табели 6, приказани су резултати остварени у свакој појединачној дисциплини при обарању светских рекорда Томпсона, О'Брајан, Дворжака, Шебрлеа и Итона. 
Табела 6 Приказ светских рекорда од 1984. до 2015. године по дисииплинама.

\begin{tabular}{|l|c|c|c|c|c|}
\hline \multicolumn{1}{|c|}{ Рекордери } & Томпсон & О'Брајан & Дворжак & Шебрле & Итон \\
\hline Светски рекорд & 8847 & 8891 & 8994 & 9026 & 9045 \\
\hline Датум постизања & $08-09.8 .1984$. & $04-05.9 .1992$. & $03-04.7 .1999$. & $26-27.5 .2001$. & $28-29.08 .2015$. \\
& Лос Анђелес & Талин & Праг & Гецис & Пекинг \\
\hline 100 т & 10,44 & 10,43 & 10,54 & 10,64 & 10,23 \\
\hline Скок удаљ & 8,01 & 8,08 & 7,90 & 8,11 & 7,88 \\
\hline Бацање кугле & 15,72 & 16,69 & 16,78 & 15,43 & 14,52 \\
\hline Скок увис & 2,03 & 2,07 & 2,04 & 2,12 & 2,01 \\
\hline 400 т & 46,97 & 48,51 & 48,08 & 47,79 & 45,00 \\
\hline 110 т препоне & 14,33 & 13,98 & 13,73 & 13,92 & 13,69 \\
\hline Бацање диска & 46,56 & 48,56 & 48,33 & 47,92 & 43,34 \\
\hline Скок мотком & 5,00 & 5,00 & 4,90 & 4,80 & 5,20 \\
\hline Бацање копља & 65,24 & 62,58 & 72,32 & 70,16 & 63,63 \\
\hline 1500 т & $4: 35,00$ & $4: 42,10$ & $4: 37,20$ & $4: 21,98$ & $4: 17,52$ \\
\hline
\end{tabular}

На основу резултата из табеле 6, може се закључити да су приликом обарања светског рекорда одлучивале нијансе, а упоређујући резултате по дисциплинма може се уочити следеће:

- у трци на 100 m најбољи резултат остварио је Итон, а најслабији Шебрле, а да разлика у трци на 100 m између најбољег и најслабијег резултата износи 0.41 секунду;

- у трци на 110 m препоне најбољи резултат оставарио је Итон, а најслабији Томпсон, а разлика између најслабијег и најбољег резултата износи 0.64 секунде;

- остварени резултати у трци на 110 m препоне О'Брајана, Дворжака и Шебрлеа указују на њихову уједначеност;

- резултати Итона у трци на $100 \mathrm{~m}$ и трци на $110 \mathrm{~m}$ препоне, указује на висок ниво његових спринтерских могућности, док резултат Томпсона указује да он своју брзину није успео искористити у трци на $110 \mathrm{~m}$ препоне, што се може оправдати његовом лошом техником трчања преко препона;

- приликом постизања светског рекорда најбоље резултате у трци на 400 m остварили су Томпсон (46.97) и Итон (45.00), чији резултат уједно представља и најбољи резултат на $400 \mathrm{~m}$ икада остварен у десетобоју;

- у скоку удаљ Томпсон, О'Брајан и Шебрлесу приликом постизања светског рекорда оставарили су даљине преко осам метара, док су мање даљине постигли Дворжак (7.90) и Итона (7.88);

- у скоку увис уочава се уједначеност у оствареним резултатима код Томпсона, О'Брајана, Дворжака и Итона (разлика између најбољег и најслабијег резултата износи $6 \mathrm{~cm}$ ), док је најбољи резултат остварио Шебрле (2.12 m); 
- у бацању кугле уочава се уједначеност постигнутих резултата Томпсона (15.72 m) и Шебрлеа $(15.43 \mathrm{~m})$ са разликом од $29 \mathrm{~cm}$, и О'Брајана $(16.69 \mathrm{~m})$ и Дворжака $(15.43 \mathrm{~m})$ са разликом од 26 $\mathrm{cm}$, док је Итон остварио најслабији резултат (14.52 m);

- у бацању диска резултати О'Брајана (48.56 m), Дворжака (48.33 m) и Шебрлеа (47.92 m) указују на уједначеност у овој дисциплини, док је нешто слабији резултат постигао Томпсон $(46.56 \mathrm{~m})$, а најслабији Итон (43.34 m);

- резултати у бацању копља указују да је Дворжак (72.32 m) остварио врхунски резултат, као и Шебрле $(70.16 \mathrm{~m})$, док су остали рекордери остварили приближно уједначене резултате са малом разликом бодова (табела 7);

- у трци на 1500 m најслабији резултат остварио је О'Брајан (4:42.10), а најбољи Итон (4:17.52).

На основу изнетог може се закључити да је, светски рекорд Томпсону донела трка на $400 \mathrm{~m}$, Дворжаку врхунски резултат у бацању копља, Шебрлеу изванредан резултат за десетобојце у последњој дисциплини, Итону сјајан резултат на $400 \mathrm{~m}$, затим и резултати у осталим спринтерским дисциплинама, као и остварен резултат у скоку мотком, док је О'Брајан светски рекорд оборио захваљујући резултатима у првих осам дисциплина.

Изнад просека су за десетобојце резултати Итона и Шебрлеа на 1500 m. Томпсон, О'Брајан и Дворжак можда нису били приморани на одличан резултат у последњој дисциплини, да би срушили светски рекорд, Итон и Шебрле су били одлучни да постигну што боље резултате у последњој дисциплини.

Садашњи рекордер Итон има најбоља достигнућа у спринтерско-скакачким дисциплинама. Његови резултати у овим дисциплинама су знатно бољи од резултата ранијих светских рекордера. Међутим, просечни резултати у бацачким дисциплинама (за једног десетобојца), су му онемогућили већу бодовну разлику у односу на остале рекордере.

У табели 7, приказана је структура бодова у односу на први и други дан такмичења у десетобоју, као и број бодова остварених у спринтерским, скакачким и бацачким дисциплинама приликом постизања светског рекорда Томпсона, О'Брајана, Дворжака, Шебрлеа и Итона. 
Табела 7 Структура освојених бодова у десетобоју при постизању светског рекорда.

\begin{tabular}{|l|c|c|c|c|c|}
\hline & Томпсон & О'Брајан & Дворжак & Шебрле & Итон \\
\hline \multicolumn{1}{|c|}{ Светски рекорд } & 8847 & 8891 & 8994 & 9026 & 9045 \\
\hline Датум постизања & $08-09.8 .1984$. & $04-05.9 .1992$. & $03-04.7 .1999$. & $26-27.5 .2001$. & $28-29.08 .2015$. \\
Лос Анђелес & Талин & Праг & Гецис & Пекинг \\
\hline Година старости & 26 & 26 & 27 & 27 & 27 \\
\hline Први дан (бодови) & 4677 & 4720 & 4645 & 4675 & 4703 \\
\hline Други дан (бодови) & 4170 & 4171 & 4349 & 4351 & 4342 \\
\hline Разлика & 507 & 559 & 296 & 324 & 361 \\
\hline Спринт & 2881 & 2854 & 2881 & 2846 & 3115 \\
\hline Скокови & 2804 & 2859 & 2775 & 2853 & 2815 \\
\hline Бацања & 2450 & 2511 & 2660 & 2529 & 2286 \\
\hline Максим. разлика & 431 & 348 & 221 & 324 & 829 \\
\hline После девет дисци. & 8135 & 8224 & 8296 & 8228 & 8216 \\
\hline 1500 т & $4: 35,00(712)$ & $4: 42,14(667)$ & $4: 37,20(698)$ & $4: 21,28(798)$ & $4: 17,52(829)$ \\
\hline
\end{tabular}

Анализом приказаних података у табели 7, може се уочити да су светске рекорде десетобојци остварили у 26 , односно 27. години живота.У складу са наведеним, може се закључити да су у периоду од 1984 . до 2015. светске рекорде у десетобоју постизали атлетичари просечне старости 26.6 година, и да су то, према постигнутим светским рекордима, најбоље године за постизање врхунског резултата у десетобоју. На исти закључак указују Ванг (Wang) и Лу (Lu) у свом истраживању 2007. године. Уједно, Билић и сарадници (2015) упоредном анализом доминантних предиктора утврдили су, да дисциплине чији резултат више зависи од техничке ефикасности извођења, представљају пресудне одреднице резултатске успешности у десетобоју, а која се стиче зрелошћу такмичара. 


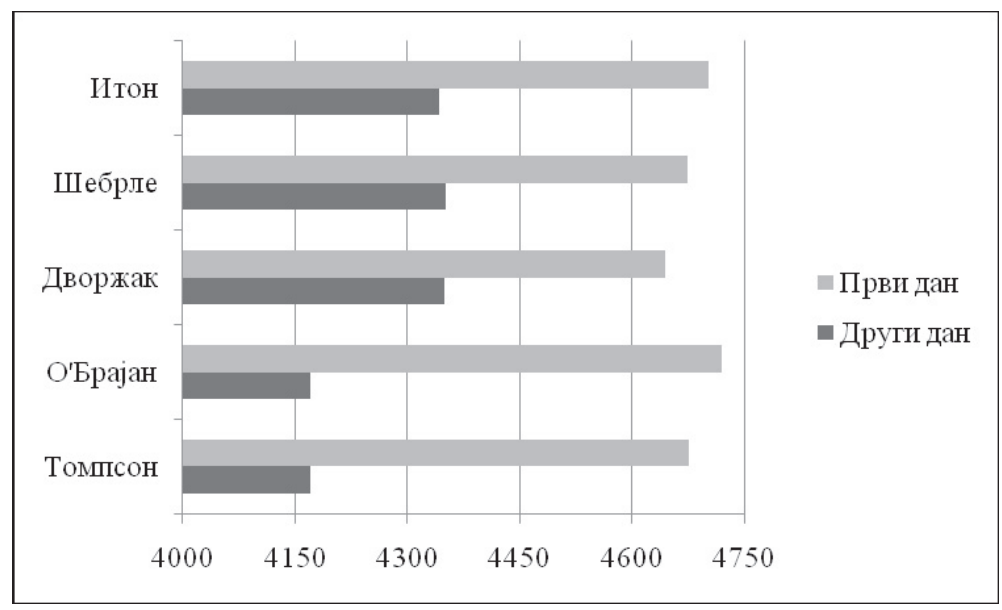

Графикон 2 Освојени резултати првог и другог дана за сваког светског рекордера

На основу остварених бодова првог и другог дана, приказаних у табели 7 и графикону 2, може се уочити да су десетобојци приликом постизања светских рекорда, остваривали већи број бодова првог, него другог дана такмичења. Анализом разлике остварених бодова првог и другог дана такмичења у десетобоју, приликом обарања светског рекорда, уочава се да је највећу разлику имао О'Брајан (559), а најмању Дворжак (296). Када се упоређују бодови освојени првог и другог дана, већа уједначеност се уочава код чешких рекордера.

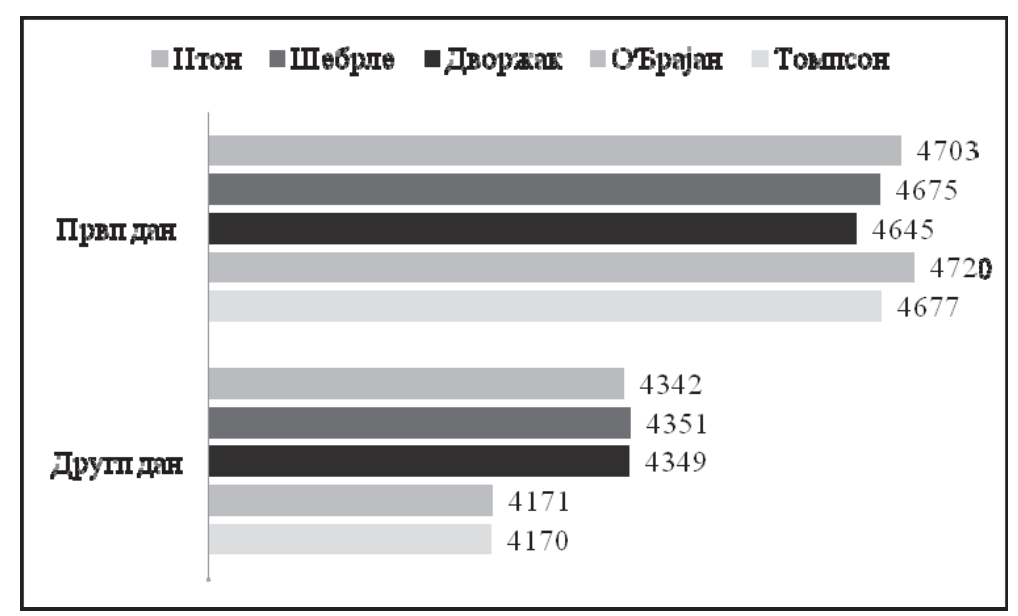

Графикон 3 Међусобни однос освојених резултата првог и другог дана између светских рекордера 
Број бодова остварених првог, односно другог дана такмичења (табела 7, графикон 3) указују да су највећи број бодова, приликом обарања светског рекорда, првог дана остварили О'Брајан (4720) и Итон (4703), а најмање Дворжак (4645), док су Томпсон (4677) и Шебрле (4675) били прилично уједначени (разлика само два бода). У току другог дана такмичења, уочава се да су највећи број бодова остварили Шебрле (4351), Дворжак (4349) и Итон (4342), а најмање Томпсон (4170), као и О'Брајан са 4171 бодова.

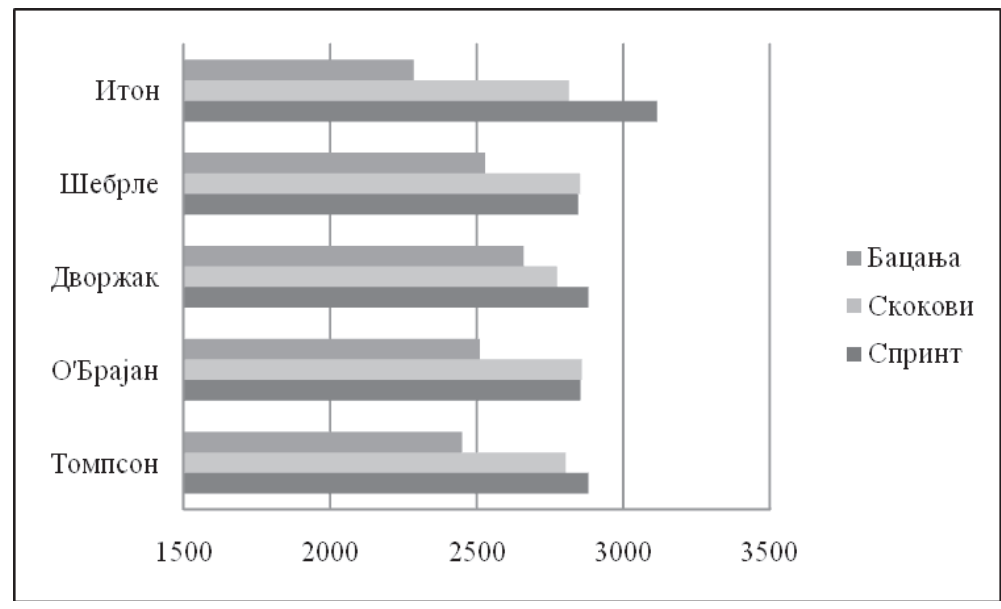

Графикон 4 Освојени бодови у спринтерским, скакачким и бацачким дисииплинама без остварених бодова у трии на $1500 \mathrm{~m}$

На основу остварених бодова у спринтерским, скакачким и бацачким дисциплинама (табела 7 , графикон 4) уочава се, да ниједан светски рекордер нема тзв. „слабу“ дисциплину у десетобоју. Према броју освојених бодова, спринтерске дисциплине доминирају, затим скакачке, а бацачке дисциплине су за нијансу слабије од осталих дисциплина десетобоја. Највећа уједначеност се уочава код Дворжака, код којег максимална разлика у бодовима између најбољих (спринтерских) и најслабијих (бацачких) дисциплина износи 221 бода.42Прототип класичног типа десетобојца (спринтер-скакач) и то са доминантним резултатима у спринтерским дисциплинама има Итон, са највећом разликом између спринтерских и бацачких дисциплина (829 бодова). Постигнућа у спринтерским и скакачким дисциплинама код О'Брајана и Шебрлеа, одликују се ретком уједначеношћу, мада је О'Брајан постизао фантастичне резултате у у скакачким дисциплинама.

У табели 8, приказан је однос личних рекорда (ЛР) у појединачним дисциплинама и резултата остварених приликом обарања светског рекорда.

\footnotetext{
${ }^{42}$ Иако су му бацачке дисциплине најслабије, Дворжак је врхунским резултатом у бацању копља, остварио светски рекорд.
} 
Табела 8 Однос светских рекорда и личних рекорда светских рекордера у појединачним дисциплинама

\begin{tabular}{|c|c|c|c|c|c|c|c|c|c|c|}
\hline & \multicolumn{2}{|c|}{ Томпсон } & \multicolumn{2}{|c|}{ О'Брајан } & \multicolumn{2}{|c|}{ Дворжак } & \multicolumn{2}{|c|}{ Шебрле } & \multicolumn{2}{|c|}{ Итон } \\
\hline Дисциплина & ЛР & CP & ЛР & CP & ЛP & CP & ЛP & CP & ЛP & CP \\
\hline $100 \mathrm{~m}$ & 10,26 & 10,44 & 10,23 & 10,43 & 10,54 & 10,54 & 10,64 & 10,64 & 10,21 & 10,23 \\
\hline Скок удаљ & 8,11 & 8,01 & 8,11 & 8,08 & 8,07 & 7,90 & 8,11 & 8,11 & 8,23 & 7,88 \\
\hline Бацање кугле & 16,10 & 15,72 & 16,69 & 16,69 & 16,88 & 16,78 & 16,36 & 15,33 & 15,40 & 14,52 \\
\hline Скок увис & 2,14 & 2,03 & 2,20 & 2,07 & 2,09 & 2,04 & 2,15 & 2,12 & 2,11 & 2,01 \\
\hline $400 \mathrm{~m}$ & 46,86 & 46,97 & 46,53 & 48,51 & 47,56 & 48,08 & 47,76 & 47,79 & 45,00 & 45,00 \\
\hline 110 m препоне & 14,04 & 14,33 & 13,47 & 13,98 & 13,61 & 13,73 & 13,68 & 13,92 & 13,35 & 13,69 \\
\hline Бацање диска & 49,10 & 46,56 & 55,07 & 48,56 & 50,28 & 48,33 & 49,37 & 47,92 & 47,36 & 43,34 \\
\hline Скок мотком & 5,25 & 5,00 & 5,25 & 5,00 & 5,10 & 4,90 & 5,20 & 4,80 & 5,40 & 5,20 \\
\hline Бацање копља & 65,24 & 65,24 & 66,90 & 62,58 & 72,32 & 72,32 & 71,10 & 70,16 & 66,64 & 63,63 \\
\hline $1500 \mathrm{~m}$ & $4: 20,30$ & $4: 35,00$ & $4: 33,19$ & $4: 42,10$ & $4: 29,69$ & $4: 37,20$ & $4: 21,98$ & $4: 21,98$ & $4: 14,48$ & $4: 17,52$ \\
\hline Десетобој & 9315 & 8847 & 9572 & 8891 & 9296 & 8994 & 9318 & 9026 & 9543 & 9045 \\
\hline
\end{tabular}

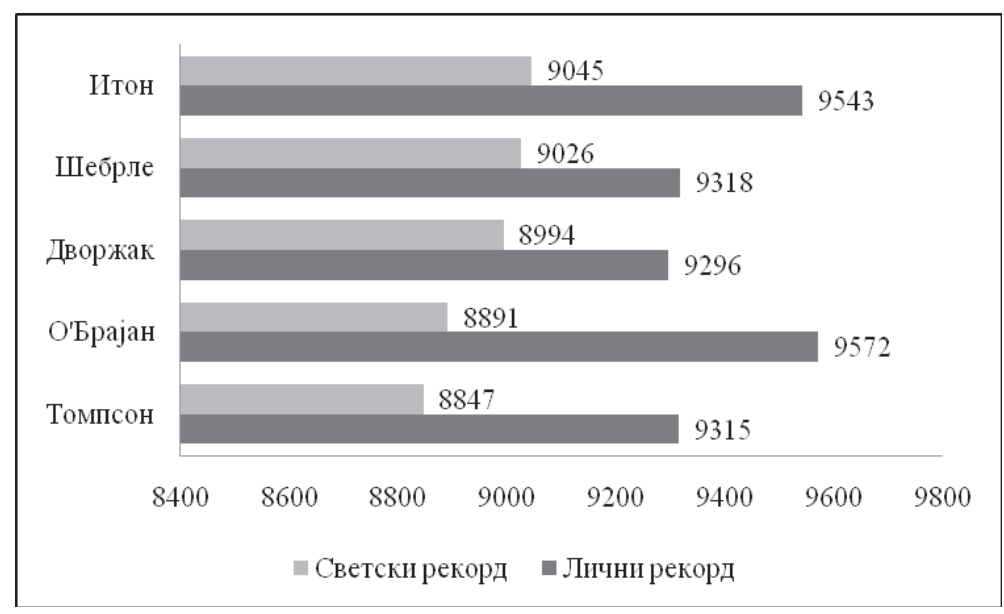

Графикон 5 Однос светског рекорда и личних рекорда у појединачним дисциплинама 
Резултати приказани у табели 8 и графикону 5 , указују да лични рекорди светских рекордера знатно надмашују резултате постигнуте у десетобоју, који је у том тренутку био светски рекорд и да, када би се они рачунали, остварени бодови у десетобоју би били значајно бољи. Приказани резултати указују, да су десетобојци у поједним дисциплинама постизали резултате, на нивоу врхунских резултата у тим дисциплинама и да би се у њима могли такмичити на светском нивоу. Поједини резултати су чак бољи од државних рекорда неких земаља.43

У табели 9 приказан је процентуални однос збира личних рекорда и светских рекорда Томпсона, О'Брајана, Дворжака, Шебрлеа и Итона.

Табела 9 Прочентуални однос збира најбољих резултата у појединим дисииплинама и светских рекорда

\begin{tabular}{|c|c|c|c|c|c|}
\hline & Томпсон & О'Брајан & Дворжак & Шебрле & Итон \\
\hline Индекс успешности & $94,97 \%$ & $92,88 \%$ & $96,75 \%$ & $96,86 \%$ & $94,78 \%$ \\
\hline
\end{tabular}

На основу анализе резултата приказаних у табели 8 и 9, као и графикона 4, долази се до следећих закључака.

У најбољем десетобоју свих времена, Итон је успео да оствари $94.78 \%$ од својих могућности. Приликом постизања тренутно важећег светског рекорда, Итон је успео да оствари један лични рекорд у појединачним дисциплинама, а остали резултати су ми били просечни у односу на његове раније остварене резултате и могућности. Поред врхунског резултата на $400 \mathrm{~m}$, тактичком трком на $1500 \mathrm{~m}$ и резултатом 4:17.52 успео је да надмаши дотадашњи (свој) светски рекорд. Анализа Итонових резултата наводи на закључак, да ће током наредне 2016, на Олимпијским играма у Рио де Женеиру остварити нови светски рекорд.

За разлику од Итона, приликом обарања светског рекорда Шебрле је успео да оствари $96.86 \%$ од својих могућности, што указује да је поред изваредних физичких могућности, психолошки био веома стабилан. Приликом обарања рекорда, у три дисциплине је побољшао своје личне рекорде, док је у осталим дисциплинама био на нивоу својих најбољих резултата.

Дворжак је један од ретких десетобојаца који је био приближно уједначен у свим дисциплинама. Разлика у освојеним бодовима у скакачким, спринтерским и бацачким дисциплинама је веома мала. Анализирајући његов светски рекорд, може се уочити неколико одличних резултата, али је дефинитивно резултат остварен у бацању копља $(72.32 \mathrm{~m})$, резултат са којим је Дворжак оборио светски рекорд. На основу резултата светског рекорда Дворжака, може се уочити побољшање личних рекорда у само две дисциплине. Међутим, његов индекс успешности је високих (96.75\%), што указује да је у осталим дисциплинама био на нивоу личних рекорда.

О'Брајан је био најбољи десетобојац 90-их година прошлог века, ако не и најбољи свих времена. По мишљењу многих тренера и стручњака био је далеко најсвестранији десетобојац, а можда и најбољи десетобојац свих времена. О'Брајан је једноставно био добар у свим дисциплинама што указује и збир његових личних рекорда у појединим дисциплинама од 9572 бода. Приликом обарања светског рекорда он је постигао само један лични рекорд у појединачним дисциплинама, а остали резултати су били далеко слабији, али је ипак поставио светски рекорд. Једина „мрља“ у његовом десетобоју је трка на 1500 $\mathrm{m}$, иако је имао одличан лични рекорд у тој дисциплини (4:33.19). ${ }^{44}$ Због тога је и његов индекс успешности свега $92.88 \%$.

\footnotetext{
${ }^{43}$ Итонов резултат на $400 \mathrm{~m}$, бољи је од државног рекорда Србије, као и Томпсонов, О'Брајанов и Итонов на $100 \mathrm{~m}, 3 а т и м ~$ О'Брајанов и Итонов на $110 \mathrm{~m}$ са препонама, али и резултати Томпсона, О'Брајана и Итона у скоку мотком.

${ }^{44}$ Познато је да је О’Брајанова психа била његов највећи проблем.Тако је на такмичењима увек знао да ће бити први и да нема разлога за врхунским достигнућем у трци на $1500 \mathrm{~m}$.
} 
Томпсон је био неприкосновени владар десетобоја 80-их година прошлога века. Сматрало се да ће тај резултат бити недостижан за остале десетобојце, па чак и за њега самог. Његови резултати наводе на закључак, да он спада у спринтерско-скакачки типа десетобојца. Фантастични резултати у овим дисциплина су му донели светски рекорд, али у исто време због њих тај резултат није био још бољи. У десетобоју који му је донео светски рекорд, подбацио је баш у тим дисциплинама. Његови најбољи резултати су много бољи него они које је он постигао приликом обарања светког рекорда. Због тога и његов индекс успешности износи $94.97 \%$.

\section{4. Закључци}

Након анализе светских рекорда пет најсвестранијих десетобојаца свих времена Ештона Итона, Романа Шебрлеа, Томаша Дворжака, Ден О'Брајана и Дејли Томпсона, који представљају врхунска спортска достигнућа у десетобоју, може се извести неколико закључака.

Анализом најбољих резултата и светских рекорда, од 1984. до 2015. године, може се закључити да је за врхунски резултат потребан природан таленат, а да је пут до њега пропраћен развојем специфичне дисциплине, подсистемом који је делимично не спојив са подсистемима перформанси у другим дисциплинама.

Упоредном анализом пет светских рекорда утврђено је да, дисциплине чији резултат више зависи од техничке ефикасности извођења него од нивоа базичних моторичких способности, представљају пресудне одреднице врхунског резултата у десетобоју. При томе, истакнуте дисциплине су спринтерска трчања, скок у даљ и скок с мотком, а након тога бацање копља. Закључује се, да ће у наредном периоду ове дисциплине имати своју прогресију, и да ће наредни светски рекорд бити постигнут врхунским достигнућима у овим дисциплинама.

Уједно, може се закључити да, десетобојци више нису диференцирани према групи дисциплина и да нема специјализације за неку од дициплина десетобоја, већ се тежи хармоничном развоју за шта је потребно између пет и десет година. Успех у десетобоју захтева хармоничан развој моторичких и функционалних способности. Десетобојац треба да влада брзином спринтера, издржљивошћу и брзинском издржљивошћу тркача на средње стазе, снагом бацача и, на крају општом издржљивошћу, која омогућава тренинге и наступе на такмичењима у току дужег времена. Иако је потребно истовремено развијати све моторичке способности, извесна предност се даје брзини и брзинској издржљивости.

\section{5. Литература}

Bervall, E. (1913). The official report of the Olympic Games of Stockholm 1912. Stockholm:Wahlström \& Widstrand.

Bilić, M. (2015). Determination of taxonomic type structures of top decathlon athlets. Acta Kinesiologica, 9 (1), pp. 20-23.

Bilić, M., Balić, A. (2015).Types of discipline decathlon functional dependences in relation to age and level of score achievements of the world most successful decathlons.Sport Science, 8 (1), pp. 52-56.

Bilić, M., Smajlović, N., Balić, A. (2015). Contribution to discipline decathlon total score results in relation to decathlon age and result-level. Acta Kinesiologica, 9 (1), pp. 66-69.

Cox, T.F., Dunn, R.T. (2002).An analysis of decathlon data.Journal of the Royal Statistical Society Series D, 51, 179-187. Decathletes. New Studies in Athletics, 18(4), pp. 7-17.

IAAF Scoring Tables for Combined Events. (April, 2004), доступно 14.12.2015 на www.iaaf.org/download/IAAF\%20Scoring\%20Tables\%20for\%20 
Kenny, I.C., Sprevak, D., Sharp, C.N.C. and Boreham, C.A.G. (2005). Determinants of success in the Olympic decathlon: some statistical evidence, Journal of Quantitative Analysis in Sports, 1 (1), art. 5.

Ryba, J. A. (2009). Atletické víceboje. Praha: Olympia.

Summers, D. (2003).Longman dictionary of contemporary English. Harlow: Pearson Education Limited.

Tidow, G. (2000). Challenge Decathlon - Barriers on the Way to becoming the "King of Athletes". Part I. NSA, 15, Los Angeles.

Trkal, V. (2004). The development of combined events scoring tables and implications for the training of

Váňa, Z. (2002). The training of the best decathletes.High level coaching seminar - Combined Events. Prag: European Athletic Association.

Vindušková, J. (2002). Technical Aspects in Combined Events.In Technique in Athletics.European Athletics Coaches Association Congress in Čatez. Ljubljana: European Athletic Association, Atletska zveza Slovenije.

Wang, Z., Lu, G. (2007). The Czech Phenomenon of Men's Decathlon development.International Journal of Sports Science and Engineering, 1(3), pp. 209-214.

Woolf, A., Ansley, L., Bidgood, P. (2007). Grouping of Decathlon Disciplines.Journal of Quantitative Analysis in Sports, 3 (4), art. 5.

http://www.decathlon2000.com/, доступно 14.12.2015.

http://www.iaaf.org/disciplines/combined-events/decathlon\#topfive=1, доступно 14.12.2015. 